\title{
The distribution and availability of phosphorus fractions in restored cut slopes soil aggregates along altitude gradient
}

\author{
Mengke Zhu ${ }^{1}$, Bocong Huang ${ }^{1}$, Zongyang Liu ${ }^{2}$, yue Wang ${ }^{1}$, jiao Teng ${ }^{1}$, xiaosu Tian ${ }^{1}$, and \\ Ying-wei $\mathrm{Ai}^{1}$ \\ ${ }^{1}$ Sichuan University \\ ${ }^{2}$ Sichuan University - Wangjiang Campus
}

January 11, 2022

\begin{abstract}
The distribution and availability of phosphorus (P) fractions in restored cut slope soil aggregates along altitude gradients were studied. We examined soil aggregates total phosphorus (TP), available phosphorus (AP) and phosphorus activation coefficient (PAC), and discovered that there was no significant difference in TP at four altitudes ( $\mathrm{p}>0.05)$, but there was a significant difference in AP at $3009 \mathrm{~m}, 3347 \mathrm{~m}$ and $3980 \mathrm{~m}(\mathrm{p}<0.05)$. At $3009 \mathrm{~m}, 3347 \mathrm{~m}$ and $3654 \mathrm{~m}$, the AP accumulation in small size aggregates were more advantageous. Overall, PAC dropped steadily as aggregate size increased, as shown by PAC (3654 m) $>$ PAC $(3347 \mathrm{~m})>$ PAC $(3009 \mathrm{~m})>$ PAC $(3980 \mathrm{~m})$ in altitudes. In all particle size soil aggregates, total inorganic phosphorus $(\mathrm{TPi})>$ total organic phosphorus $(\mathrm{TPo})>$ residual phosphorus $(\mathrm{R}-\mathrm{P})$ at $3009 \mathrm{~m}, 3347 \mathrm{~m}$ and $3654 \mathrm{~m}$; TPo $>\mathrm{TPi}>\mathrm{R}-\mathrm{P}$ at $3980 \mathrm{~m}$. Through correlation and multiple stepwise regression analysis, we concluded that active NaHCO3-Pi was the main AP source. It was suggested that more attention should be paid to the ratio of small particle size aggregates, so as to increase soil AP storage. At low $(3009 \mathrm{~m})$ and high altitude $(3980 \mathrm{~m})$, inorganic $\mathrm{P}$ fertilizer and $\mathrm{P}$ activator were added into soil to improve the activation ability of soil P and the AP supply, so as to promote the healthy development of slope soils ecosystem.
\end{abstract}

\section{Hosted file}

Manuscript.docx available at https://authorea.com/users/454943/articles/552399-thedistribution-and-availability-of-phosphorus-fractions-in-restored-cut-slopes-soilaggregates-along-altitude-gradient

\section{Hosted file}

Table.docx available at https://authorea.com/users/454943/articles/552399-the-distributionand-availability-of-phosphorus-fractions-in-restored-cut-slopes-soil-aggregates-alongaltitude-gradient

\section{Hosted file}

Figure.docx available at https://authorea.com/users/454943/articles/552399-the-distributionand-availability-of-phosphorus-fractions-in-restored-cut-slopes-soil-aggregates-alongaltitude-gradient 